\title{
THE CAVERN CONCEPT OF MAIN CHARACTER IN BEAUTY AND THE BEAST
}

\author{
Mella Nur Mauliah ${ }^{1}$ and Tenny Sudjatnika ${ }^{2}$ \\ SMK Negeri 1 Tirtajaya ${ }^{1}$, \\ Universitas Islam Negeri Sunan Gunung Djati Bandung ${ }^{2}$
}

\begin{abstract}
Literature is a fiction in which the author has freedom in expressing their imagination. In viewing a film, the audience can represent the film according to what they see. This can be seen from the storyline, moral message, character, and so on. The character in a literary work elevates the aesthetic value, any character can be described by the author. It can be contained in literary works because it is an idea or imagination of someone to created aesthetic purposes. The ugliness in the character is called as grotesque. The grotesque character causes their alienation from his society because the structure of his body is ugly or odd. The researcher looked for the data relating to the question of the problem, namely, how the Cavern Concept of Beauty and The Beast is like. The researcher used descriptive method. The researchers found that there are conflicts in revealing the cavern concept includes: (1) condemnation of a Prince become an ugly figure, (2) transformation into a Beast, (3) the character's emotional changes when transforming into a Beast, and (4) the beast's alienation from his environment or his world.
\end{abstract}

Keywords: grotesque, cavern concept, alienation

\section{INTRODUCTION}

The film also consists of certain complexity that deals imaginatively with human experiences. Film is an audio-visual media to convey a message to the audience. In film, has imaginatively in a story with electronic media. Film is a strong reality, one of which tells about the reality of society. Film can also be interpreted as a form of cultural results and as a means of artistic expression. Film as mass communication of various technologies such as photography and sound recording, and art which can be in the visual arts, theatre arts, and music arts. There is an artistic film that has a high imagination following the scenario that has been made.

In viewing a film, the audience can represent the film according to what they see. This can be seen from the storyline, moral message, character, and so on. In making a film, of course, that first thing about the important roles in it. The character selection is chosen by the author as a representation of imagination produced from the author's head. They also have the authority to do whatever they want in their literary work. The author can create some characters such as a king, hero, etc. The character can be categorized as moral, behavior, and habits. Every person has a character that has been formed before. Whereas according to Sora (2015), character, trait, manner, and personality distinguishes an individual from other individuals. Every person has different character with others. Every person has a different character with others. The differences of character can be seen from the nature and physics of the person. The nature and physics can be called characteristic. There are no references in this explanation, the researcher need to put it. 


\section{LITERATURE REVIEW}

Literature is a fiction in which the author has freedom in expressing their imagination. Fiction is a story that is not real. Fiction is a story or background that comes from imagination, not based on facts and history. In literary studies, there are several fiction stories that not necessarily true, such as in film. However, there are also those who do have authenticity in the story. This can see from the reflection of true stories that are packaged through literary works. So, that it can be seen as a fiction literary work, such in animation that is lifted from a true story and then packaged through a literary device.

The character in a literary work elevates the aesthetic value. Any character can be described by the author because any idea can be pure in literary works while still acceptable to the readers. For example, a character has a nature of good and evil or created the physical character or characteristic as an ugly, odd, creepy, and unstructured body. It can be shown in literary works because it is an idea or imagination of someone to create aesthetic purposes. The ugliness in the character is called grotesque. According to Cuddon (2005, in Rudini, 2007:2), the word grotesque derives from Italian grotte 'caves', whose adjective is 'grottesco', the noun being 'la grotesca' means correct technical sense has little to do with its normal usage. The characters, including the abnormal characters, have important roles in making the fiction become interesting.

The grotesque character causes their alienation from his society because the structure of the body is ugly or odd. Thomson (in Rudini, 2007:16) has given three definitions of grotesque as the expression of the estranged or alienated world, as a game with absurd, and as an attempt to control and exorcise the demonic elements in the world. The alienation can be done to one person by destroying or even depriving the human characteristic out of him whether physically or mentally. The physical alienation has a close relationship with the monstrous or strangeness or everything which is like it. Whereas according to Conelly (2003:2), images gathered under the grotesque rubric include those that combine unlike things in order to challenge established realities or construct new ones. The opposition is contradictory, that is a contradiction between two contradictory things. The contradiction can be seen from the grotesque character that is created from an idea in a literary work. The author's idea causes a conflict between imagination and reality. That means, the author can write or pour according to what is in the contents of his head. This is including pouring ideas that are contrary to reality, such as grotesque characters. However, the reality of the grotesque character is not a few who refused to appear. Therefore, the grotesque character can cause alienation from the surrounding environment.

\section{METHOD}

In this study, the researchers used descriptive methods. According to Suryana (2010:20), the method used to look for the elements, characteristics, characteristics of a phenomenon. This method starts by collecting data, analysing data, and interpreting it. The descriptive method in its implementation is carried out through survey techniques, case studies (contrast with a case), comparative studies, studies of time and motion, behaviour analysis, and documentary analysis. The data taken by the researchers come from the Research Object film "Beauty and The Beast, 
2017". The data will be the answer to the problem question. The analysis is an attempt to observe in detail something. Which was then developed through qualitative methods, which explain in detail on the data. Researchers look for data relating to the question of the problem, how the Cavern Concept in Beauty and The Beast is like. Then the researcher will interpret the data.

\section{FINDINGS AND DISCUSSIONS}

The researchers found grotesque conflicts in the main character. Grotesque conflict was found by the cavern concept conflict in the main character. These conflicts include: (1) condemnation of a Prince become an ugly figure, (2) transformation into a Beast, (3) the character's emotional changes because he is a Beast, and (4) beast's alienation from his environment or his world.

The explanation above makes it easy for the researchers to analyze a film of Beauty and The Beast 2017. That is the circle of cavern concept contained in the narrative of film Beauty and The Beast of 2017. The circle was produced from the plot presented in the Beauty and The Beast plot. Cavern concept is an alienation concept that occurs in the main character is supported by alienation conflict. The sequence of stories can be illustrated in the following diagram.

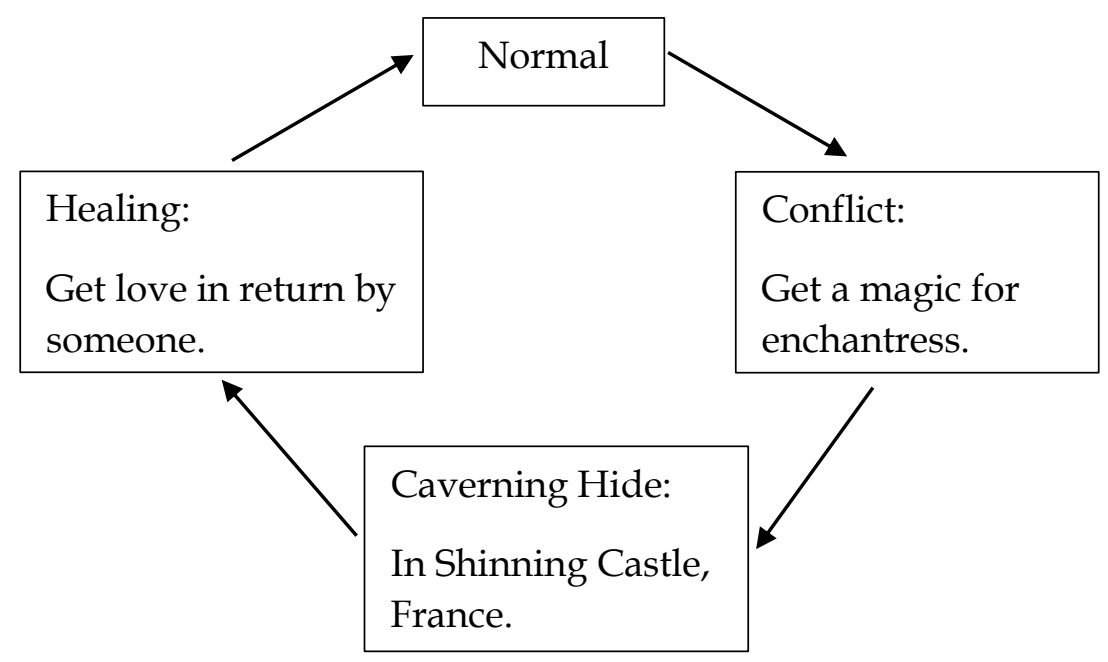

Figure 1. The circle of Cavern Concept in film "Beauty and The Beast, 2017"

Before becoming an ugly figure, the beast was a prince of a beautiful royal palace in the middle of France. The beast figure is the figure of a handsome's prince. This can be seen from the posture possessed by a prince. Here is the figure of the prince. This figure of the prince in normal condition, before he got a conflict and become ugly. 


\section{Data 1}

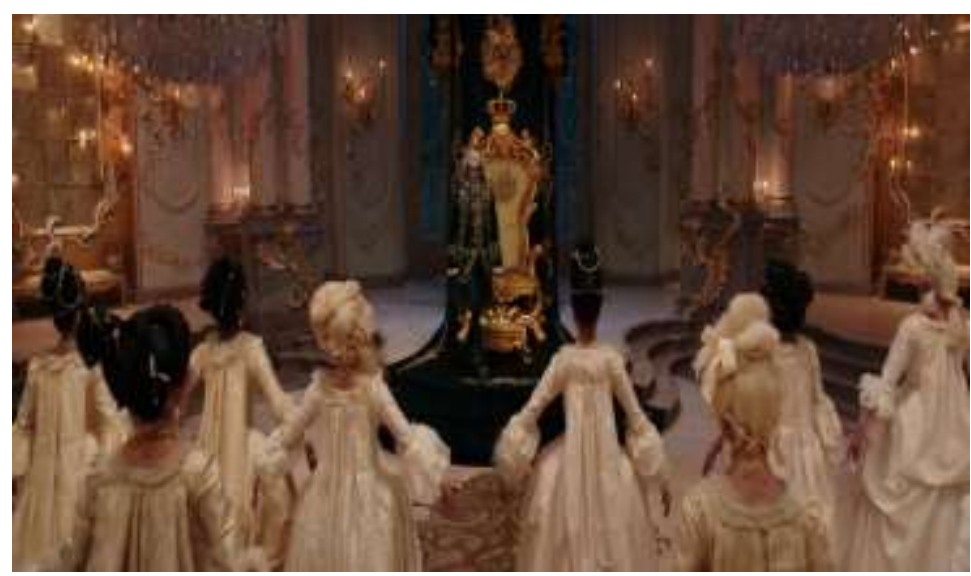

Picture 4.1.1.1 in minute (01:25)

This picture illustrates the normal condition.

"Once upon a time in a faraway land, a young prince lived in a shinning castle" (Pg. 1)

Through the quote above, the researcher found literary elements, that is, plot and symbol. These two literary devices have not revealed the cavern concept in film Beauty and The Beast 2017.

The quote above and the picture above explains the life of the prince before he experienced magic. The above quote begins with an exposition in a story. Exposition is an arrangement of the plot that is at the beginning or introduction. Exposition is an introduction to the story so that characters and settings are introduced (Sridianti, 2019). It can be seen in the phrase 'once upon a time', that phrase begins to give information at that time of a story. The introduction of the story also begins with the introduction of a Prince who lives in a shinning castle or royal palace. The figure of the prince is usually symbolized by a man who is manly, authoritative. Symbol is a sign that has a meaning. A symbol is something that can explain a form (Dictionary of Webster, 1997). This can be seen that the word 'Prince', has meaning as a boy who has royal blood. The symbol can also be seen from the meaning of the word 'kingdom'. The kingdom is a symbol that can explain an object, which is a residence for a king, queen, and royal family. As in the phrase 'shinning castle', the phrase describes a beautiful kingdom, which is the residence of a prince. This is also supported by the picture above as a picture of a handsome prince, who was sitting on his throne. The throne is a royal seat for a King's seat. However, the throne is used by a prince.

The social status of a prince also has differences with other people. Usually, the figure of the prince is identical to something different and has special features. 
In the quote and explanation above, the researchers can conclude that the above analysis contained literary elements, that is, exposition in plot and symbol of the prince and shinning castle.

\title{
Data 2
}

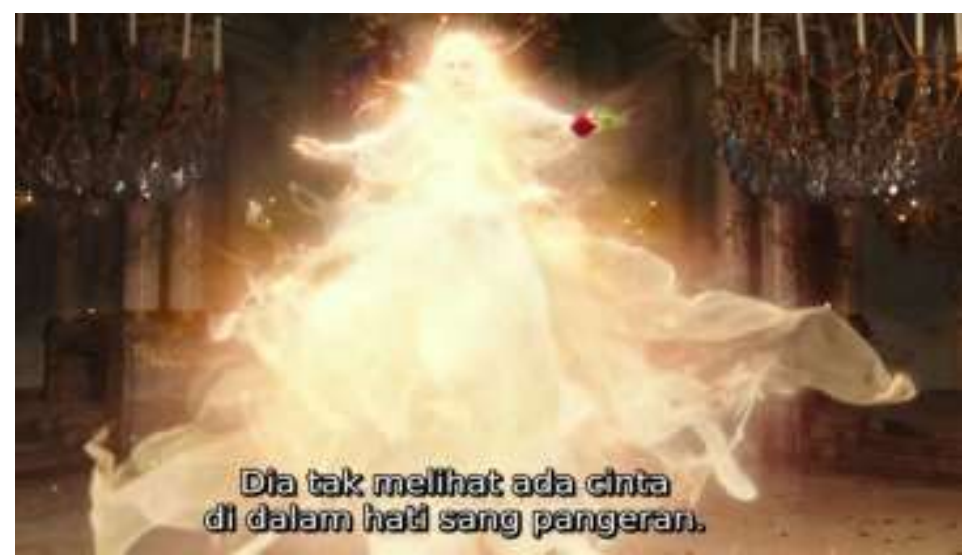

Picture 4.1.1.2 in minute (03:23)

This picture illustrates the normal conditions leading to conflict.

\author{
"but she warned him not to be deceived by appearances, for \\ beauty is found within" \\ "and when he dismissed her again, the old woman's \\ ugliness melted away to reveal a beautiful enchantress" \\ "the Prince tried to apologize, but it was too late, for she
} had seen that there was no love in his heart" (Pg. 1-2)

Through the quote above, researcher found a literary element, that is: symbol of enchantress. These literary device have not revealed the cavern concept in film Beauty and The Beast 2017.

The quote above that explains that the old woman warned prince not to be fooled by her shabby appearance. The old woman turned into a beautiful, beautiful enchantress. Enchanters is term or symbol for a witch. "symbol merupakan sesuatu yang dapat menjelaskan tentang sebuah bentuk"(Dictionary of Webster, 1997). In literature, there are symbols in the story. Symbols can be seen through an images, phrases, myths, and others. Therefore, literary works are a reflection of love. The using of symbol in literary works, is usually used to give color and give aesthetic value in higher. Enchantress or witch is a symbol of an individual who has a spell that can change anything his/her want. Witch is also an ability possessed by someone to control nature (including events, objects, people, etc) through a mysticism, paranormal, or supernatural. The witch is described as a beautiful woman. In the quote, picture, and explanation above, researcher can conclude that the above analysis contained literary elements, that is: symbol of enchantress. 


\section{Data 3}

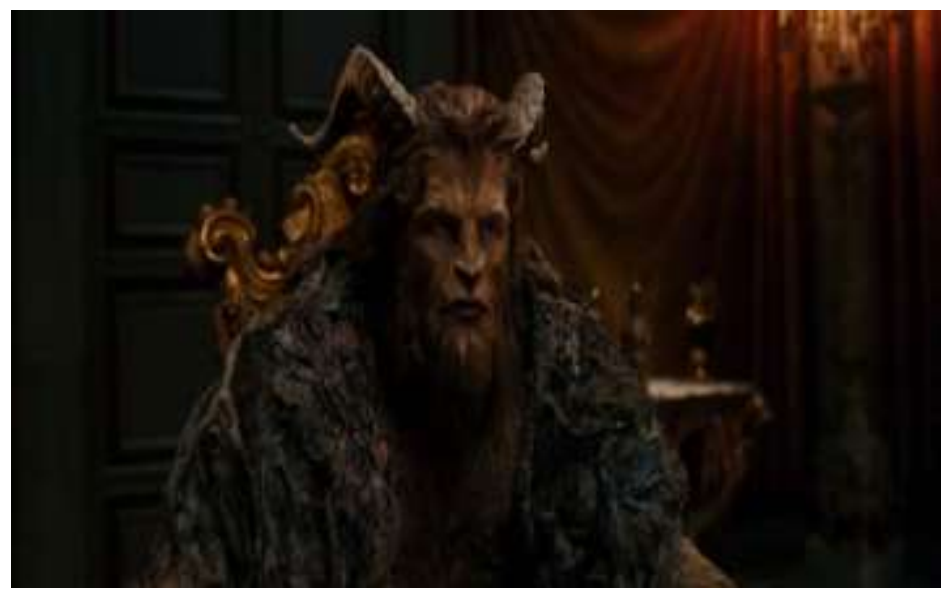

Picture 4.1.1.4 in minute (43:01)

This picture illustrates the grotesque conflict.

Through the scene or picture above, researcher found a literary elements. The two literary element, that is: grotesque character and symbol of beast. These literary device have not revealed the cavern concept in film Beauty and The Beast 2017. The picture above is a change in the physical form of prince. The change is obtained through a magic it receives by beautiful enchantress. The character turned into the incarnation of a terrible monster. The character is symbolized as a Beast. Symbol is sign to represents about a things, objects, or humans. Beast is an ugly, and savagae character, it can see in the picture above. Beast is a character of half-animal and human, who has a large of body, and creepy. As in the picture above, beast is describing of animal it has horns, fangs, large of his body, and it face is so scray. The physical structure illustrates that it has differences with normal humansin general. Because, in the magic he experienced, he had to suffering. Suffering can be seen from the physical, as well as mental.

His physical is almost the entire of body. His physical can be said as a grotesque. Grotesque is an embodiment that is experienced by humans who have abnormal in his body. This character is a human, but has no structural or disproportionate physical. Can be seen in the picture above, physical's prince is not organized or disproportionate as humans in general. Grotesque is a condition owned by someone whose ownership is not owned by humans in general. According to Conelly (2003:2), that is "Grotesque also describes (1) the aberration from ideal form or form accepted convention, to create the misshapen, ugly, exaggerated, or even formless." Grotesque character is an embodiment of ugly, excessive, or even has no form of his body. This can be seen from the physical form of a prince who is excessive and has no body structure. From his physical is mixing of a monster that has a tail, horns, has fur all over his body, and legged donkeys.

In the picture and explanation above, researcher can conclude that the above analysis contained literary elements, that is: grotesque character and symbol of beast. 


\section{Data 4}

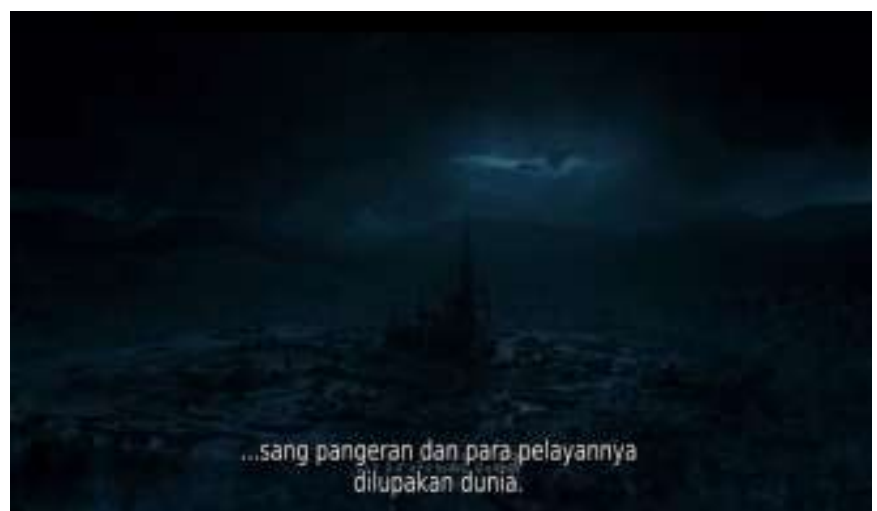

Picture 4.1.1.9 in minute (03:52)

This picture illustrates the caverning hide of beast.

"Ashamed of his monstrous form, the Beast concealed himself inside in his castle with a magic mirror as his only window to the outside world" (Pg. 2)

Through the scene or picture above, researcher found a literary element. The literary element, that is: alienation. These literary device already revealed the cavern concept in film Beauty and The Beast 2017. The impact of the grotesque character can be isolated from the environment. As in the character of the beast who experienced alienation from the environment or even in his world. The alienation is a product of the grotesque character of beast. The alienation from the beast can be seen from his castle which is so dark, far from his surroundings, and even the weather contained in his castle has a difference with near of his environment. This is the impact of the magic, cause he has arrogant's character and he became a beast. The magic also is able to change the beast like an alienated person. Both of the body, mental, to the environment. This conditions make beast feel alienated from his enviornmnet even his world, and also alienated himself. According to Matsumoto (in Marandika, 2018:302), that explains:

\footnotetext{
"alienasi" sering digunakan untuk menggambarkan sebuah keadaan di mana seseorang merasa asing dari dirinya sendiri dan dari sekitarnya, sehingga mendorong orang itu untuk bersikap bermusuhan terhadap orang lain atau masyarakat. Dengan demikan, keterasingan manusia adalah gangguan mental di mana seseorang kehilangan kendali atas dirinya sendiri”
}

The alienation also had a negative impact on beast. That is he is more unable to control himself, both from the attitude, emotions, and heart. That is because he feels that he does not care for others. This makes him a cruel and uncontrollable figure. His alienated habits make him always have emotions and don't have friends. The environment will definitely not accept it because is different. Therefore, this will cause him to be increasingly alienated or increasingly threatened.

He was estranged far from his environment. That is what causes him to not be able to control himself. According to Karl Marx (in Marandika, 2008:309), that explains, "Keterasingan adalah hasil dari milik pribadi, dan di sisi lain, kepemilikan itu sendiri merupakan produk dari manusia yang mengalami keterasingan." The private ownership is a body product by beast. Caused by a magic from an old 
woman's it is a witch. The old woman can also be said to be an alienated's person, because of its appearance. Or even the magic itself is a product of alienation, so magic is only used in fantasy stories that are completely absent from the limits of reality. It means that magic, and the old woman can also be said to be a product of human alienation.

In the picture and explanation above, researcher can conclude that the above analysis contained literary elements, that is: alienation.

\section{Data 5}

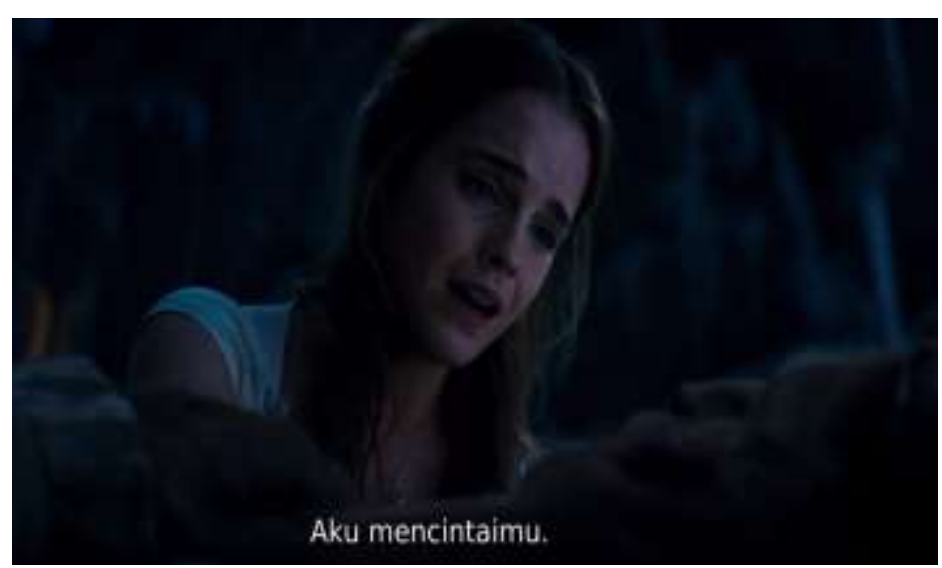

Picture 4.1.1.14 in minute (1:52:18)

This picture illustrates the conflict leading to normal condition.

The picture above explains that beast has received a love from belle. And the magic will soon end and beast will return to its normal condition. The magis is gone, beast really loves belle, and also belle. This can be seen from belle who does not want beast to leave it. This sincere love is embedded from belle's extraordinary heart. Belle's heart and love for beast have been able to broken a magic and she has turned into a kind-heart prince. Not only beast, it also applies to beast friends who experience similar magic with beast. They have also changed into their original condition. Beast, belle, and his friends are now living happily like in the picture below. 


\section{Data 6}

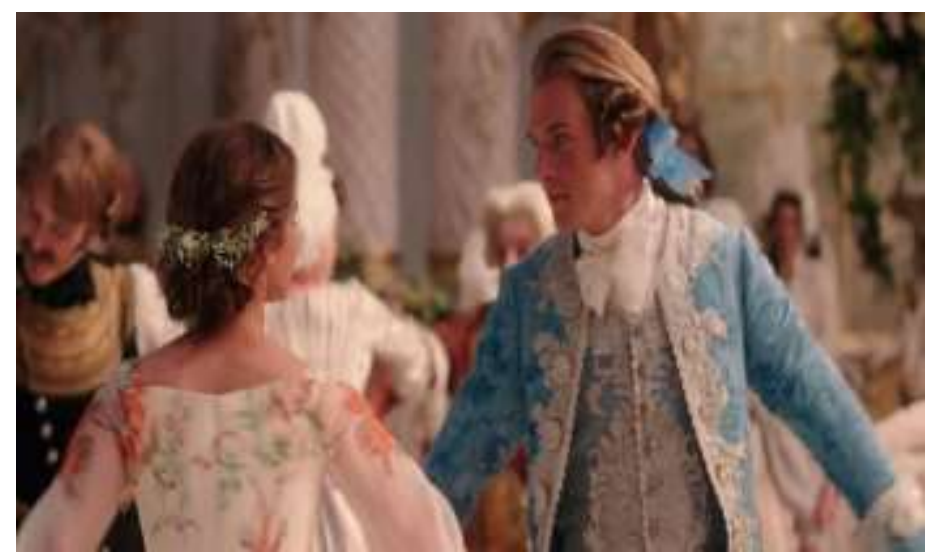

Picture 4.1.1.15 in minute (1:57:23)

This picture illustrates the normal condition after character have a conflict.

Breaking a magic spell makes beast now live happily with his true love, belle. Breaking a magic is part of a process that goes through the beast to eliminate the magic. In the literature elements, returning to normal conditions after facing a condition that has a conflict called as chatarsis. Chatarsis is a sanctification. Chatarsis applies to a plot that presents a normal condition at exposition or beginning. Then the condition are changes to the next plot or in the conflict. Then at the end of the story the conditions are changes to the normal. That plot is a chatarsis, chatarsis is a sanctification or purification of the soul after experiencing unsual changes. According to Wahyuningsih (2017:39), that explains "istilah katarsis berasal dari bahasa Yunani, kathoros, yang berarti 'untuk menyucikan' atau 'untuk membersihkan'. The term of is used for beast, because in this case condition of the beast has changed to normal condition. The term chatarsis is also used as a process of a conflict that occurs in the beast, in this cas a myth. According to term of chatarsis by Aristotle, chatarsis is not an activity, in this case it is a magic that occurs only once at the same time. Chatarsis is a process, in this case the process of broken magic spell with beast must learn to love other people, it is belle. The process must be carried out as well as possible by beast. If the magic break process goes well, then the beast's condition will return to normal. Because, the concept of chatarsis itself is the purification of one's soul after experiencing an extraordinary event and is able to pass it well. The process is called chatarsis.

In the picture and explanation above, researcher can conclude that the above analysis contained literary elements, that is: chatarsis.

\section{CONCLUSIONS}

That plot is chatarsis, chatarsis is a sanctification or purification of the soul after experiencing unsual changes. Then the condition are changes to the next plot or in the conflict. Then at the end of the story the conditions are changes to the normal.

Breaking a magic spell makes beast now live happily with his true love, belle. Breaking a magic is part of a process that goes through the beast to eliminate the magic. In the literature elements, returning to normal conditions after facing a condition that has a conflict called as catharsis. The catharsis is applied for this beast 
because in this case, the beast has changed to normal condition. The term catharsis is also used as a process of a conflict that occurs in the beast, namely, a myth. According to by Aristotle, the term catharsis is not an activity but a magic that occurs only once at the same time. The concept of catharsis itself is the purification of one's soul after experiencing an extraordinary event and is able to pass it well. Catharsis in this movie is a process, namely, the process of breaking magic spell by the beast to learn to love other people, and his love falls for belle. The process must be carried out as possible by the beast. If the magic breaking process goes well, the beast's condition will return to normal.

\section{REFERENCES}

Conelly, S. F. 2003. Modern Art and The Grotesque. Cambridge University Press.

Marandika, F D. Keterasingan Manusia menurut Karl Marx. Tsaqafah, Volume 14, Number 2, November 2018, 299-322.

N, Sora. 2015. Pengertian Karakter dan Pendidikan Karakter Secara Umum. Accessed on http://www.pengertianku.net/2015/11/pengertian-karakter-danpendidikan-karakter.html. Download at $11^{\text {th }}$, April 2019.

Rudini, M. 2007. The Grotesque on Jonathan Swift's Gulliver's Travels. The state Islamic University Sunan Gunung Djati Bandung.

Sridianti. 2019. Apa itu Plot? Accesed on https://www.sridianti.com/apa-ituplot.html. Download at $14^{\text {th }}$, February 2020.

Suryana. 2010. Metodologi Penelitian: Model Praktis Penelitian Kuantitatif dan Kualitatif. Universitas Pendidikan Indonesia.

Wahyuningsih, S. 2017. Teori Katarsis dan Perubahan Sosial. Komunikasi. Vol. XI. No. 01.

Pengertian Simbol: Macam Jenis, Fungsi, dan Contoh. Accessed on https://jagad.id/pengertian-simbol-macam-jenis-fungsi-dan-contoh/

Download at $4^{\text {th }}$, February 2020. 